\title{
DELIKTUELE AANSPREEKLIKHEID WEENS 'N LATE: IS DIE ONDERNEMER SY KLANT SE HOEDER?
}

\section{Inleiding}

Dit is gevestigde reg dat ' $n$ persoon wat versuim om te verhoed dat ' $n$ ander skade ly, in die reël nie deliktueel onregmatig handel nie, of soos dit kripties in Saaiman v Minister of Safety and Security (2003 3 SA 496 (O) 503) gestel word: "The general rule of delict is that no one is held liable for doing nothing. This is trite law." Positief gestel, is sodanige late dus prima facie regmatig (sien bv Telematrix (Pty) Ltd t/a Matrix Vehicle Tracking $v$ Advertising Standards Authority SA $2006 \quad 1$ SA 461 (HHA) 468; Mediterranean Shipping Co (Pty) Ltd v Tebe Trading (Pty) Ltd [2007] 2 All SA 489 (HHA) 494; vgl Gouda Boerdery BK v Transnet 20055 SA 490 (HHA) 498; Trustees, Two Oceans Aquarium Trust v Kantey \& Templer (Pty) Ltd 20063138 (HHA) 143; Transitional Council of Delmas v Boshoff 20055 SA 514 (HHA) 522; en Stewart $v$ Botha 20086 SA 310 (HHA) 314-315). "Onderliggend aan dié uitgangspunt is die gedagte dat niemand sy broer se hoeder is nie" (Minister van Veiligheid en Sekuriteit v Geldenhuys 20041 SA 515 (HHA) 528). Regsbeleidsoorwegings hiervoor is onder andere dat ' $n$ algemene regsplig om benadeling van andere deur positiewe optrede te voorkom, 'n te swaar las op persone in die gemeenskap sou plaas, asook dat dit tot chaos kon lei "[i]f every individual were liable for failure to protect others against loss", aangesien "each would be compelled, in order to avoid liability, to run around and busy himself with the affairs of his neighbours" (sien Van den Heever Aquilian Damages in South African Law (1944) 3738). "Society is [dus] hesitant", soos dit in Cape Town Municipality v Bakkerud (2000 3 SA 1049 (HHA) 1054) verwoord word, "to impose liability in law for, as it is sometimes put, "minding one's own business"'. Daarom moet daar in elke besondere geval bepaal word of daar inderdaad ' $n$ regsplig was om positief op te tree ten einde benadeling te vermy, en dit word beantwoord aan die hand van die redelikheids- of boni moresonregmatigheidsmaatstaf (sien in die algemeen Neethling, Potgieter en Visser Deliktereg (2006) 53-54; en Van der Walt en Midgley Principles of delict (2005) 84-85). In Van Eeden $v$ Minister of Safety and Security (Women's Legal Centre Trust, as amicus curiae) (2003 1 SA 389 (HHA) 395; sien ook Minister of Safety and Security v Hamilton 20042 SA 216 (HHA) 229) word dit so gestel:

"The appropriate test for determining wrongfulness [of an omission] has been settled in a long line of decisions of this Court. An omission is wrongful if the defendant is under a legal duty to act positively to prevent the harm suffered by the plaintiff. The test is one of reasonableness. A defendant is under a legal duty to act positively to prevent harm to the plaintiff if it is reasonable to expect of the defendant to have taken positive measures to prevent the harm." 
In die onlangse tyd het daar 'n hele paar gevalle voor die howe gedien waar klante van ondernemers op sakepersele benadeel is. Drie sodanige gevalle verdien nadere beskouing, naamlik waar 'n klant op 'n gladde winkelvloer gly en beseer word, waar 'n klant op 'n besigheidsperseel geskiet word, en waar 'n klant se motor op die parkeerterrein van 'n besigheid gesteel word. In al hierdie gevalle is die primêre vraag of die betrokke ondernemer sy klant se hoeder is, met ander woorde, of daar ' $n$ regsplig op die ondernemer gerus het om die klant se benadeling te voorkom het. Sekondêr kom die vraag na die ondernemer se nalatigheid (en kousaliteit) ter sprake.

\section{$2 \quad$ Glipperige winkelvloer}

Vir sover dit die sogenaamde "slippery shop floor" -beslissings aangaan (sien bv Lindsay $v$ Checkers Supermarket 20084 SA $634(\mathrm{~N})$; Monteoli $v$ Woolworths (Pty) Ltd 20004 SA 735 (W); Probst v Pick 'n Pay Retailers (Pty) Ltd [1998] 2 All SA 186 (W); en vgl Chartaprops 16 (Pty) Ltd v Silberman 20091 SA 265 (HHA) 274-275), is daar eenstemmigheid in die regspraak dat daar ' $n$ regsplig op winkeleienaars rus om die besering van klante weens glyery op die winkelvloer te voorkom. Daar word dus redelikerwys van hulle verwag om voorkomende maatreëls in hierdie verband te tref. Hier is die feit dat die winkeleienaar feitelike beheer gehad het oor 'n potensieel gevaarlike toestand, naamlik die winkel waar klante op gladde vloere kan gly, aanduidend van die bestaan van die regsplig (sien Neethling Potgieter en Visser Deliktereg 59-62; en vgl ook Chartaprops 16 (Pty) Ltd v Silberman supra 274). In Probst v Pick 'n Pay Retailers (Pty) Ltd (supra 200) (sien ook Lindsay v Checkers Supermarket supra 637; en vgl Chartaprops 16 (Pty) Ltd v Silberman supra 274-275) word die regsplig soos volg omskryf:

"It is trite law as confirmed in judgments from our courts over an extensive period, that shopkeepers owe a duty to persons entering their shops during trading hours, to take reasonable steps to ensure that, at all times during trading hours, the floor was kept in a condition that was reasonably safe for shoppers, bearing in mind that they would spend much of their time in the shop with their attention focused on goods displayed on the shelves, or on their trolleys, and not looking at the floor to ensure that every step they took was safe."

Alhoewel hierdie dictum in die algemeen instemming verdien, word die betrokke regsplig ongelukkig so omskryf dat dit onregmatigheid en nalatigheid omspan. Die indruk word naamlik geskep dat die regsplig te make het met die vraag of die verweerder redelike veiligheidstappe gedoen het al dan nie; dit wil sê of hy soos die redelike persoon in die omstandighede gehandel het - dus die vraag na nalatigheid. Hierdie benadering kan lei tot ' $n$ algehele opname van die nalatigheidstoets by die bepaling van onregmatigheid. Op sy beurt kan dit tot gevolg hê dat die kern van die onregmatigheidstoets negeer word, naamlik of daar volgens die boni mores ' $n$ regplig bestaan het - oftewel of daar redelikerwys van die betrokkenene verwag kon word om positief op te tree ten einde die aantasting van 'n regtens-beskermde belang (hier die fisiese-psigiese integriteit) te voorkom. Boonop is hierdie formulering ' $n$ weerspieëling van die klassieke Engelsregtelike "duty of care"-benadering "which straddles 
both elements of wrongfulness and negligence" (Trustees, Two Oceans Aquarium Trust $v$ Kantey \& Templer (Pty) Ltd supra 144), en wat uitdruklik deur die Hoogste Hof van Appèl verwerp is (bv Transitional Council of Delmas $v$ Boshoff supra 522; en Telematrix (Pty) Ltd t/a Matrix Vehicle Tracking $v$ Advertising Standards Authority SA supra 468). In die lig hiervan behoort die howe hulle benadering in hersiening te neem en die twee delikselemente duidelik te onderskei (sien in die algemeen Neethling en Potgieter "Wrongfulness and Negligence in the Law of Delict: A Babylonian Confusion?" 2007 THRHR 123-124). 'n Ligpunt blyk nietemin uit die minderheidsuitspraak van Nugent AR in Chartaprops 16 (Pty) Ltd $v$ Silberman (supra 274-275) waar hy verklaar dat "[i]t seems to me that it is reasonable to expect a person in control of a shopping mall to ensure that reasonable precautions are taken to keep the floors safe and is liable if those precautions are not taken by a person whom he or she has appointed to do so" (my kursivering). Sodoende word 'n duidelike onderskeid gemaak tussen die redelike verwagting dat stappe gedoen sal word (die regspligonregmatigheidskwessie: sien Van Eeden v Minister of Safety and Security (Women's Legal Centre Trust, as amicus curiae) (supra 395, hierbo aangehaal) en die redelikheid van die uitvoering daarvan (die nalatigheidsvraag). Nieteenstaande die feit dat Willis $\mathrm{R}$ in Monteoli $v$ Woolworths (Pty) Ltd (supra 745-745) ook poog om onregmatigheid en nalatigheid in die onderhawige gevalle uitmekaar te hou, trap hy ongelukkig klei waar hy ook die uitvoering van die regsplig onder onregmatigheid eerder as nalatigheid wil betrek. Hy verklaar naamlik ten onregte dat die funksie van die getuienis wat oor bedoelde uitvoering voorgelê is, "was not so much to rebut an inference of negligence ... that arose res ipsa loquitur but rather to prove that the defendant had acted in a manner consistent with its admitted legal duty ('regsplig') to its customers. It operated, in other words, to exclude the element of wrongfulness rather than rebut an inference of negligence".

Hoe ook al, uit verreweg die meerderheid uitsprake oor die glipperige winkelvloer-gevalle blyk duidelik dat die howe die bestaan van 'n regsplig en dus onregmatigheid - as 'n gegewe aanvaar en dat die verdere ondersoek net die vraag na nalatigheid betrek. Hier word die klassieke redelike voorsien- en voorkombaarheidstoets vir nalatigheid, soos omskryf in Kruger $v$ Coetzee (1966 2 SA 428 (A) 430), as uitgangspunt aanvaar en die voorkombaarheids-been aangepas en toegepas op die glipperige winkelvloer-gevalle, en wel soos volg (Probst v Pick 'n Pay Retailers (Pty) Ltd supra 200; sien ook Lindsay v Checkers Supermarket supra 635-636; Chartaprops 16 (Pty) Ltd v Silberman supra 275):

"The duty on the keeper of a supermarket to take reasonable steps is not so onerous as to require that every spillage must be discovered and cleaned up as soon as it occurs. Nevertheless, it does require a system which will ensure that spillages are not allowed to create potential hazards for any material length of time, and that they will be discovered, and the floor made safe, with reasonable promptitude."

Dit spreek vanself dat die stelsel nie net toereikend moet wees nie, maar inderdaad ook nagekom moet word (Chartaprops 16 (Pty) Ltd v Silberman supra 275). Te veel klem moet egter nie gelê word op die tydsduur wat enige bemorsing op die vloer bly voordat dit ontdek word nie aangesien sodanige duur op sigself kunsmatig en onrealisties sou wees - die toereikendheid van 
die stelsel as geheel moet uiteraard in ag geneem word (Lindsay $v$ Checkers Supermarket supra 638). Nalatigheid kan deur middel van res ipsa loquitur bepaal word waar die omstandighede 'n prima facie afleiding van nalatigheid regverdig (Monteoli v Woolworths (Pty) Ltd supra 737-738).

Waar die winkeleienaar die taak om die besigheid skoon van gemors te hou aan 'n onafhanklike kontrakteur opgedra het, sien die posisie effe anders daaruit. Die winkeleienaar kan naamlik net aanspreeklik gehou word vir skade wat die lashebber veroorsaak het indien eersgenoemde self ook ' $n$ delik begaan het (Chartaprops 16 (Pty) Ltd $v$ Silberman supra 284; vgl Langley Fox Building Partnership (Pty) Ltd v De Valence 19911 SA 1 (A) 7ev; en Neethling, Potgieter en Visser 360 vn 118). Dit is onder andere die geval waar daar 'n gevaar van skadeberokkening aan derdes (klante) aan die lashebber se taak verbonde was en die lasgewer (winkelier) nalatig versuim het om die gevaar af te weer (Langley Fox Building Partnership (Pty) Ltd v De Valence supra 9-13 en 18). Of dit so is, word volgens Langley Fox Building Partnership (Pty) Ltd v De Valence supra 11-12 aan die hand van die volgende drie vrae beantwoord (wat tiperend van die toets vir nalatigheid in ons reg is: sien Chartaprops 16 (Pty) Ltd v Silberman supra 284):

"(1) Would a reasonable man have foreseen the risk of danger in consequence of the work he employed the contractor to perform? If so, (2) would a reasonable man have taken steps to guard against the danger? If so, (3) were such steps duly taken in the case in question? Only where the answer to the first two questions is in the affirmative does a legal duty arise, the failure to comply with which can form the basis of liability."

Op die keper beskou, stel hierdie benadering die winkelier-lasgewer se aanspreeklikheid egter net van sy nalatigheid afhanklik sonder om ook die vraag na onregmatige optrede aan sy kant pertinent te beantwoord; en hier kom die regspligbenadering by aanspreeklikheid weens ' $n$ late ter sprake wat, soos gesê, volgens die boni mores-maatstaf bepaal moet word - oftewel aan die hand daarvan of daar redelikerwys van die winkelier verwag kon word om op te tree. By die vasstelling van die regsplig speel faktore soos die verhouding tussen die partye, die beheer oor 'n gevaarlike situasie en die feit dat die winkelier geweet het van die gevaarlike toestand 'n rol (sien Neethling, Potgieter en Visser 60 vn 144 en 66-67). So gesien, word die minderheids-benadering van Botha AR in Langley Fox Building Partnership (Pty) Ltd v De Valence (supra 16-20) verkies aangesien die toepassing van die redelike persoon-nalatigheidstoets volgens hom afhanklik is van "the state of the employer's knowledge relating to the actual existence of a dangerous situation at the very time when harm befalls a third party" (Langley Fox Building Partnership (Pty) Ltd v De Valence supra 17), dit wil sê van die onregmatigheidsvraag of daar hoegenaamd 'n regsplig op die winkelier gerus het om positief op te tree ( $\mathrm{vgl}$ Neethling, Potgieter en Visser 151 oor die onderskeid tussen nalatigheid en onregmatigheid by aanspreeklikheid weens ' $n$ late). Hierdie benadering word by implikasie ook nagevolg deur Kriegler WnAR in Minister of Community Development $v$ Koch (1991 3 SA 751 (A) 761-762) vir sover hy daarin slaag om die beslissing van Botha AR in Langley Fox Building Partnership (Pty) Ltd v De Valence supra (wetebenadering) met dié van Goldstone WnAR (redelike persoon-benadering) te versoen (Neethling en Potgieter "Deliktuele aanspreeklikheid by die lasgewer-lashebber-verhouding" 1992 THRHR 311-313). In hierdie verband 
word de lege ferenda aan die hand gedoen dat daar volgens die boni mores 'n regsplig op lasgewers in die algemeen en winkeliers in die besonder rus om net onafhanklike kontrakteurs aan te stel wat geskik en bekwaam is vir 'n taak wat 'n gevaar of risiko van benadeling inhou waarvan die lasgewer (redelikerwys) bewus is. Waar dit inderdaad gedoen is, is die lasgewer nie verplig om enige verdere stappe te doen om die risiko uit te skakel nie tensy, en dit is baie belangrik, hy bewus was of kennis gedra het van die "actual existence of a dangerous situation at the very time when harm befalls a third party" (Minister of Community Development v Koch supra 761-762), of indien sodanige gevaar redelikerwys voorsienbaar was (vgl oor die rol van redelike voorsienbaarheid by onregmatigheid bv Telematrix (Pty) Ltd t/a Matrix Vehicle Tracking $v$ Advertising Standards Authority SA supra 468; Steenkamp NO v Provincial Tender Board, Eastern Cape 20063 SA 151 (HHA) 159-160; Gouda Boerdery BK v Transnet supra 498-499). Waar dit die geval is, is daar volgens die boni mores 'n regsplig op die lasgewer om stappe te doen ten einde die skade af te weer (sien vir 'n algemene bespreking Neethling en Potgieter "Delictual Liability of Employer (Mandator) for Damage Caused by Independent Contractor" 2009 THRHR 661).

\section{$3 \quad$ Skietery op besigheidsperseel}

In 'n droewe land soos Suid-Afrika, waar die misbruik van vuurwapens 'n alledaagse verskynsel is en meesal met die verwonding of dood van slagoffers gepaard gaan, is dit eintlik verbasend dat daar sedert 2006 nog net twee gerapporteerde gevalle voor die howe gedien het waar die aanspreeklikheid van 'n ondernemer vir die verwonding van 'n klant op die terrein van of in sy sakeonderneming, onder die loep geneem is. Die leidende beslissing is Tsogo Sun Holdings (Pty) Ltd v Qing-He Shan (2006 6 SA $537(\mathrm{HHA})$ ). Hier is ' $\mathrm{n}$ gereelde klant (eiser) van 'n casino (verweerder) deur 'n ander klant op die parkeerterrein geskiet. Die kernvraag was of daar ' $n$ regsplig op die verweerder gerus het om die veiligheid van sy sakeperseel vir klante teen die gebruik van vuurwapens te verseker deur hulle aan 'n lyfdeursoeking te onderwerp, veral aangesien die casino kort tevore aan 'n rooftog onderworpe was. Die blote navraag by 'n klant of hy 'n vuurwapen by hom het, was volgens die eiser nie voldoende om bedoelde regsplig na te kom nie. Die verhoorhof gee die eiser gelyk, maar die bestaan van 'n regsplig, en bygevolg onregmatige optrede aan die kant van die verweerder, word in appèl deur Harms AR oortuigend soos volg ontken: Volgens hom (540) is die vraag "what legal duty did [die casino] have vis-à-vis a patron ... to protect him from harm by another patron who uses the same facilities", oftewel op grond van welke beleidsoorwegings sou 'n ondernemer verplig kon word om klante teen aanranding deur ander klante te beskerm deur hulle byvoorbeeld te verhinder om vuurwapens op die besigheidsperseel te dra? Hy vervolg:

"No constitutional considerations arise on the facts here. The only factor the High Court took into consideration was the fact that there had been an armed robbery by a gang of robbers some time before this event. As I understand the reasoning, every person who enters a facility open to the public must be fully searched for the possession of weapons if the facility has, in the past, been the subject of an armed robbery. If this were correct, life in this country would become unbearable and the duty cast on owners and occupiers limitless. 
Many (if not the majority) of banks and petrol service stations, for instance, have been subjected to an armed robbery and many a local corner store, too. Passengers have been shot on trains, buses and taxis. Must those in control all employ security guards for the sake of clients and is it to be expected that every client has to be bodily searched before being allowed to enter the premises or use public transport? I think not.

Courts have to be pragmatic and realistic, and have to take into consideration the wider implications of their findings on matters such as these. By its judgment, the High Court unconsciously created a new class of virtually limitless vicarious liability. I therefore come to the conclusion that [die casino] did not, under the circumstances of this case, have a legal duty to protect [die eiser teen die ander klant in casu]."

In die lig van hierdie ontkenning van onregmatige optrede aan die kant van die verweerder is dit verbasend dat die hof $(540-542)$ nogtans voortgaan en ondersoek instel na nalatigheid by die verweerder asook of daar 'n kousale verband tussen sy late en die eiser se skade was. Hierop word nie verder ingegaan nie (hieroor Scott "Casino Operator not Liable for Delictual Act Committed by One Patron Against Another" 2007 THRHR 502 505-506) behalwe om te konstateer dat die hof die regsplig-onregmatigheidsvraag en die redelike persoon-nalatigheidsvraag suiwer uitmekaar hou.

Hierdie onderskeid word egter nie so duidelik in Govender $v$ Salgados Fruiters t/a Lyndhurst Fruit Basket Basket (2009 1 SA 500 (W)) gemaak nie ten spyte daarvan die beslissing in Tsogo met goedkeuring aangehaal word (508). Hier is 'n klant (eiser) beseer toe hy deur 'n rower in 'n groentewinkel geskiet is. Die eienaars het geweier om aan die rower se eis om geld te voldoen. Daar word te kenne gegee dat dat hierdie optrede tekort geskiet het aan dié van die redelike persoon omdat die eiser se nadeel redelikerwys voorsien- en voorkombaar was (506), en dat die eienaars daarom hulle "duty of care" teenoor die eiser verbreek het. Die eiser beweer ook dat daar 'n "legal duty" op die eienaars van die winkel gerus het om hom te beskerm terwyl hy in die winkel was (506). Hierteenoor voer die verweerders aan dat die eiser, voor die nalatigheidskwessie aandag geniet, eers moet aantoon dat daar ' $n$ regsplig op die eienaars gerus het om aan die rower se onregmatige eis te voldoen, welke regsplig hoegenaamd nie regtens erkenning behoort te geniet nie (507). Mathopo R (508) bevind dat die eienaars nie nalatig gehandel het nie, en dat die eiser se steun op die verbreking van 'n "duty of care" teenoor hom dus misplaas was. Hierbenewens het kousaliteit ontbreek aangesien die eiser deur sy eie optrede - hy het geweier om op die rower se bevel plat te val en boonop gepoog om sy eie vuurwapen uit te trek - sy beserings veroorsaak het. Ten slotte laat die regter (508) hom soos volg oor die bestaan van 'n "duty of care" in die onderhawige omstandighede uit, en sluit sodoende aan by Harms AR in Tsogo Sun Holdings (Pty) Ltd v Qing-He Shan (supra) se ontkenning van die bestaan van 'n regsplig op ondernemers om klante te beskerm teen aanranding deur ander klante deur middel van vuurwapens:

"In my view to extend the duty of care in such circumstances would make life in this country unbearable and cast too wide a duty on shop owners and occupiers. A majority of banks and shops have experienced a spate of unprecedented armed robberies, and to expect them to comply with unlawful demands of armed robbers will be casting the duty too wide and is impractical." 
Alhoewel die resultaat van die uitspraak instemming verdien, gaan dit mank aan 'n klinkklare onderskeid tussen onregmatigheid en nalatigheid. Die versuim om hierdie delikselemente te onderskei kan waarskynlik toegeskryf word aan die hof se gebruik van die verwarringstigtende "duty of care "-begrip in verband met sowel onregmatigheid as nalatigheid (sien ook hierbo). In hierdie verband kan howe gerus kennis neem van die volgende verhelderende dictum van Scott AR in Mclntosh v Premier, KwaZulu-Natal (2008 6 SA 1 (HHA) 8-9):

"[T]he word 'duty' and sometimes even the expression 'legal duty' [in the context of the second leg of the test for negligence as formulated by Holmes JA in Kruger $v$ Coetzee supra], must not be confused with the concept of 'legal duty' in the context of wrongfulness which ... is distinct from the issue of negligence. I mention this because this confusion was not only apparent in the arguments presented to us in this case but is frequently encountered in reported cases. The use of the expression 'duty of care' is similarly a source of confusion. In English law 'duty of care' is used to denote both what in South African law would be the second leg of the inquiry into negligence and legal duty in the context of wrongfulness. As Brand JA observed in ... [Trustees, Two Oceans Aquarium Trust v Kantey \& Templer (Pty) Ltd supra 144] ... 'duty of care' in English law 'straddles both elements of wrongfulness and negligence'."

\section{$4 \quad$ Diefstal en saakbeskadiging op parkeerterrein}

Daar kan redelikerwys nie van ondernemings verwag word om hulle klante se eiendom op die parkeerterrein van die besigheid te beveilig nie (teen bv diefstal of saakbeskadiging). Sodanige regsplig sou 'n te swaar las op ondernemings plaas. Waar ' $n$ klant egter redelikerwys staatmaak op 'n skyn wat deur 'n ondernemer verwek word dat laasgenoemde die veiligheid van sy eiendom sal verseker, rus daar wel volgens die boni mores 'n regsplig op die ondernemer om benadeling teenoor hom te voorkom ( $\mathrm{vgl}$ Compass Motors Industries (Pty) Ltd v Callguard (Pty) Ltd 19902 SA 520 (W) 530531; vgl nietemin Longueira $v$ Securitas of Souty Africa (Pty) Ltd 19984 SA 258 (W) 260-261; sien in die algemeen Neethling, Potgieter en Visser 6869). ' $n$ Sterk rigtingwyser na die bestaan van sodanige regsplig is klaarblyklik die feit dat klante bewus was van die sekerheidsdiens en daarom daarop staatgemaak het dat die ondernemer stappe sou doen om hulle eiendom te beveilig. In Compass Motors Industries (Pty) Ltd $v$ Callguard (Pty) Ltd (supra 530) gaan die hof egter te ver waar hy te kenne gee dat ' $n$ regsplig uit die blote bestaan van ' $n$ onderneming afgelei kan word, dit wil sê waar persone nie eers werklik bewus is van bestaande beskermingsmaatreëls nie. Die blote bestaan van 'n onderneming kan beslis tog nie op sigself 'n skyn wek dat sekuriteits-maatreëls ter beskerming van klante bestaan nie (hieroor Neethling en Potgieter "Deliktuele aanspreeklikheid weens 'n late: 'n Nuwe riglyn vir die regsplig om positief op te tree" 1990 TSAR 763ev). Afgesien van onreg-matigheid, moet nalatigheid aan die kant van die ondernemer natuurlik ook bewys word. Hier is die vraag, soos hierbo aangedui, of die ondernemer in die lig van redelik voorsienbare skade aan die eiendom van klante, redelike stappe gedoen het om hulle eiendom te beveilig. In Compass Motors Industries (Pty) Ltd $v$ Callguard (Pty) Ltd (supra 525-526) maak Van Zyl R egter ook nie 'n duidelike onderskeid tussen onregmatigheid en nalatigheid nie. Inteendeel, 
volgens hom is die toets vir nalatigheid bepalend vir die vraag na die regsplig (by onregmatigheid) en die begrippe "legal duty" en "duty of care" word ten onregte as sinonieme gebruik (sien hierbo vir kritiek). Hy laat hom soos volg oor aanspreeklikheid uit:

"This is dependent on whether or not the defendant owes a legal duty or 'duty of care' to the plaintiff. If indeed such a duty does exist, the next question is whether there has been a negligent breach thereof.

The test to be applied in establishing whether a duty has come into existence between litigating parties may be found in the well-known dictum of Holmes JA in Peri-Urban Areas Health Board v Munarin 19653 SA 367 (A) 373F-G:

'I owe a duty if a diligens paterfamilias, that notional epitome of reasonable prudence, in the position in which I am in, would

(a) foresee the possibility of harm occurring to him; and

(b) take steps to guard against its occurrence."'

Indien die onderneming kontraktueel die beveiliging van die parkeerterrein aan 'n sekuriteitsfirma as onafhanklike kontrakteur oorgedra het, behoort die posisie soos hierbo uiteengesit, daaruit te blyk. (Terloops kan ook genoem word dat sodanige kontrak aanduidend kan wees van 'n deliktuele regsplig teenoor klante wat op die sekuriteitsfirma rus om hulle eiendom te beveilig (vgl Compass Motors Industries (Pty) Ltd v Callguard (Pty) Ltd supra; Cartaprops supra 276; Neethling, Potgieter en Visser 68). In Chartaprops 16 (Pty) Ltd v Silberman (supra 276) maak Nugent AR dit duidelik dat "the assumption of contractual obligations is capable of giving rise to delictual liability". Hierop word nie verder uitgebrei nie.)

\section{$5 \quad$ Samevatting}

As uitgangspunt is die ondernemer nie sy klant se hoeder nie. Dit is slegs die geval waar daar redelikerwys (of volgens die boni mores) van die ondernemer verwag kan word om stappe te doen om sy klante teen benadeling te beskerm. Of sodanige regsplig op die ondernemer rus om positief op te tree, verg ' $n$ waardeoordeel waarby die totaal van die omstandighede van die besondere geval, asook alle relevante faktore en beleidsoorwegings oorweeg moet word. Indien daar wel 'n regsplig bestaan (soos by die glipperige winkelvloer-gevalle), is die volgende vraag dié na nalatigheid, te wete of die ondernemer sy regsplig soos 'n redelike persoon uitgevoer het, oftewel of hy redelike maatreëls ter beveiliging van sy klante getref het. Langs hierdie weg word die redelike verwagting dat stappe gedoen sal word (die regsplig-onregmatigheidskwessie) en die redelikheid van die uitvoering daarvan (die nalatigheidsvraag) duidelik onderskei en moontlike verwarring tussen hierdie twee delikselemente uitgeskakel. Daarenteen, waar 'n regsplig weens byvoorbeeld beleidsoorwegings (soos waar klante deur rowers of ander klante geskiet word) en bygevolg onregmatigheid ontbreek, is die vraag na nalatigheid aan die kant van die ondernemer irrelevant. 